Iwona Anna NDiaye

Uniwersytet Warmińsko-Mazurski w Olsztynie

Wydział Humanistyczny

Instytut Słowiańszczyzny Wschodniej

tel. +48 606719496

e-mail: anna.ndiaye@uwm.edu.pl

ORCID ID: https://orcid.org/0000-0003-3881-0474

\title{
O tożsamości rosyjskiej literatury emigracyjnej (proza Nadieżdy Teffi)
}

Słowa kluczowe: N. Teffi, rosyjska emigracja, tożsamość literacka

Amerykański lingwista Joshua Fishman określił następujące komponenty etniczno-językowej świadomości pisarzy emigracyjnych: „poczucie świętości”, „poczucie pokrewieństwa” oraz „poczucie moralnego imperatywu” 1 [Fishman 1996, 2-3]. W najnowszych opracowaniach powyższe zagadnienia rozpatrywane są $\mathrm{w}$ kontekście nieuchronności redefiniowania obu kultur i kształtowania się, jak pisała Brigitta Helbig-Mischewski, trzeciej, „,hybrydycznej” jakości: „Nie jest tak, że mieszkając najpierw w jednym, a potem w innym kraju, emigrant po prostu wzbogaca się o drugi, dodatkowy punkt widzenia. Na ogół zarówno paradygmat kultury, z której się wywodzi, jak i kultury, w której zagościł, jest przez niego poddawany rewizji, postrzegany jako konstrukcja. W procesie tożsamościowym, jaki przechodzi migrant, nie dochodzi do prostej syntezy obu kultur, lecz do ich zderzenia i przenikania się, w wyniku którego wypracowana zostaje trzecia, hybrydyczna jakość” [Helbig-Mischewski 2009, 160-161]. Owa „trzecia jakość" stanowi przedmiot analizy tzw. literaturoznawstwa interkulturowego,

1 W oryginale: sense of sanctity, sense of kinship, sense of moral imperative. Podaję w tłumaczeniu Beaty Tarnowskiej, zob. [Tarnowska 2004: 108-109]. 
które postrzega tożsamości kulturowe jako zjawiska dynamiczne, „będące bardziej procesem niż stanem, efektem »negocjacji« i dialogu, konstytuujące się w spotkaniu z tym, co obce, a więc przez doświadczenie »dyferencji «" [Helbig-Mischewski 2009, 161].

Wielu literaturoznawców dostrzega ten fenomen i bada twórczość współczesnych pisarzy emigracyjnych w nowym kontekście kulturowym, tj. literaturę pisaną przez Rosjan w USA, Niemczech, Francji itd. Przedmiotem naszej analizy będzie tożsamość rosyjskiej literatury emigracyjnej, ze szczególnym uwzględnieniem kontekstu kulturowego. Przy czym, mówiąc o emigracji, mamy na myśli jej pierwszą falę, przypadającą na lata 1917-1940². A zatem tzw. białych emigrantów, którzy opuścili Rosję po przewrocie bolszewickim ${ }^{3}$. Wśród nich znaleźli się najwybitniejsi przedstawiciele elity intelektualnej, w tym wielu filozofów, pisarzy i poetów.

Egzystencja w obcym kulturowo środowisku wymuszała redefiniowanie wielu pojęć. Rosyjscy emigranci stanowili dość homogeniczną grupę, której członków łączyło to samo poczucie dyslokacji oraz świadomość określenia tożsamości kulturowej w nowych warunkach politycznych, społecznych i językowych. W tym procesie ważne miejsce zajmowała literatura, która pełniła rolę swoistego archiwum kulturowego. Twórczość literacką na obczyźnie cechowała potrzeba artykułowania przynależności do konkretnego narodu, określonej konfesji, z wyeksponowaniem atrybutów umacniających poczucie kulturowego zakorzenienia w historii przedrewolucyjnej Rosji [Haкашидзе 2014, 114-118].

2 W wielu pracach - pod wpływem Gleba Struve - historię rosyjskiej literatury emigracyjnej datuje się od 1920 roku. Natomiast zdaniem Bronisława Kodzisa za jej początki należy uznać koniec 1917 roku, gdy za granicą pojawiły się pierwsze grupki rosyjskich pisarzy, odrzucających przewrót październikowy. Por. [Kodzis 2002, 25; Kodzis 2001, 130-149].

3 Emigracja w latach 1917-1940 była zjawiskiem masowym. Liczbę tych, którzy udali się na przymusową emigrację lub zostali wydaleni przez rząd sowiecki szacuje się na kilka milionów osób. Janina Sałajczykowa odnotowywała: „Emigracja rosyjska okresu porewolucyjnego była też zapewne najliczniejsza ze wszystkich dotychczasowych. Nie ma jednak zgodności, gdy chodzi o dane liczbowe podawane przez różne organizacje i instytucje. Marek Rajew przytacza następujące liczby: Amerykański Czerwony Krzyż w listopadzie 1920 roku podał cyfrę 1965500 osób; niemiecki historyk Hans von Rimscha podaje na 1921 rok liczbę 2935 000. W 1930 roku Liga Narodów podała, że w Europie znajduje się 500 tysięcy uchodźców z Rosji, natomiast biura krajowe do spraw uchodźców podawały 829 tysięcy oraz 50 tysięcy na Dalekim Wschodzie" - zob. [Sałajczykowa 2003, 14; Por. [Раев 1994, 38]. Władimir Abdank-Kossowski twierdził, że w ciągu pierwszych lat po rewolucji kraj opuściło około trzech milionów Rosjan [Абданк-Коссовский 956, 127]. Z kolei Jewgienij Czełyszew - że od trzech do czterech milionów [Челышев 1993, 32]. Dla porównania $\mathrm{w}$ oficjalnych publikacjach radzieckich w haśle „biała emigracja” podano liczbę 860000 (Великая советская энииклопедия, 1933). Szerzej na ten temat - zob. [NDiaye 2009, 92-99]. 
Jednocześnie przedmiotem szczególnej uwagi pisarzy emigracyjnych w naturalny sposób stawała się zmieniająca się rzeczywistość oraz nowy kontekst kulturowy. O zainteresowaniu zagadnieniem autoidentyfikacji, wynikającej z nowego ujmowania tożsamości jednostki, pisała m.in. Barbara Czapik: „Literatura, jak żadna z innych gałęzi sztuki, notuje poruszenia, jakich doznajemy w kontakcie z rzeczywistością, ze światem i drugim człowiekiem, oddaje wysiłek towarzyszący poszukiwaniom identyfikacji i procesowi budowania tożsamości. Ukazuje też tragizm doświadczeń negatywnych: niewiary, załamania, zagubienia, upadku, skażenia fałszem i niegodziwością, napiętnowania szaleństwem i patologiczną dwoistością. Jest zatem ciągiem śladów pozwalających rekonstruować proces zdobywania i budowania tożsamości, a także jej tracenia i ponownego odzyskania" [Czapik 1992, 7].

Istotnymi w warunkach emigracji pozostają wzajemne uwarunkowania oraz związki pomiędzy językiem (sytuacją językową) a tożsamością ${ }^{4}$ Pisarze, posiadający różnorodne kompetencje językowe ${ }^{5}$ oraz przebywający w obcym językowo i kulturowo środowisku, stali przed bardzo ważnym wyborem ideowym i artystycznym: pisać w języku ojczystym dla czytelnika-emigranta czy tworzyć w nowym języku ${ }^{6}$. Dla przedstawicieli pierwszej fali emigracji kwestie języka ojczystego miały fundamentalne znaczenie. Poza funkcją komunikacyjną, pełnił on dwie zasadnicze funkcje: informacyjną jako sposób tworzenia i upowszechniania wiedzy, wartości, tradycji itp., oraz integrującą, która odzwierciedlała emocjonalny stosunek do języka. Dlatego rosyjscy emigranci, chociaż doskonale znali języki obce, przede wszystkim francuski i niemiecki, pozostali wierni ojczystemu. Jednocześnie jednak utwory emigrantów były nasycone odwołaniem do języków obcych.

Bogatą panoramę zjawisk językowych odnajdujemy w publicystyce oraz prozie emigracyjnej Nadieżdy Teffi (właśc. Buczyńska, z d. Łochwicka, 1872-1952), która na emigracji w Paryżu spędziła ponad trzydzieści lat.

\footnotetext{
4 Na temat związków między językiem a tożsamością powstała bogata literatura przedmiotu. Za kanoniczne należy uznać publikacje polskiego językoznawcy, etnolingwisty i slawisty Jerzego Bartmińskiego, za którym będziemy traktować język jako „,skarbnicę wartości kulturowych dziedziczonych z tradycji”. Warto w tym kontekście przypomnieć również kulturową teorię języka w ujęciu Janusza Anusiewicza, który uznaje język za najważniejszy fakt w obrębie kultury, zasadniczy jej składnik i jednocześnie za warunek jej istnienia, a kulturę ujmuje aksjologicznie, jako zbiór wartości wytworzonych i przekazywanych przez daną wspólnotę językową. Zob. [Anusiewicz 1991].

5 Urodzeni w rodzinach o bogatych tradycjach literackich, artystycznych, akademickich, od wczesnego dzieciństwa władali obcymi językami: przede wszystkim francuskim, ale także niemieckim i angielskim.

6 Szerzej na temat zjawiska bilingwizmu w rosyjskiej poezji emigracyjnej - zob. [NDiaye 2009, 118-129].
} 
Emigracyjna twórczość Teffi bardzo szybko osiągnęła popularność porównywalną z tą w Rosji. Szeroki rozgłos jej prozie zapewniały przystępna forma i treść. Czytelnicy bez trudu identyfikowali się z realiami i bohaterami świata przedstawionego, w którym wszystko wydawało się znajome i bliskie: tematyka bytowa, realizm sytuacyjny, biedny drobnomieszczanin borykający się z paradoksami otaczającego świata itd. Jednak pod cienką warstwą satyry i ironii uważny czytelnik skrywały się ogromne pokłady refleksji i nostalgii. Satyrycznej wizji rzeczywistości w groteskowych scenach z życia emigrantów przeciwstawiała Teffi liryczne dygresje, które nieśmiało wybrzmiewały na kartach jej utworów już w pierwszych miesiącach emigracji, aby z czasem przybrać na sile.

Materiał do analizy został przez nas wyodrębniony na podstawie felietonów, esejów oraz opowiadań włączonych do zbiorów prozy wydanych na emigracji, które stanowiły swoistą kronikę doświadczenia wygnania. W takich zbiorkach opowiadań, jak Ryś (Pbıcb, 1923) i Miasteczko (Городок, 1927), Teffi demaskowała absurdy emigracyjnego bytu, z kronikarską drobiazgowością opisywała tragiczne sytuacje z życia współrodaków, którzy w Konstantynopolu, Paryżu, Berlinie, Harbinie i Pradze... stworzyli osobliwe społeczności. Zwyczaje owego emigracyjnego środowiska utrwaliła m.in. w zbiorze opowiadań Miasteczko (Городок), w którym opisywała życie paryskich ulic (rue de Passy), zamieszkałych przez rosyjskich emigrantów. W tytułowym opowiadaniu Miasteczko z 1927 roku wyrażała żal z powodu tragicznego nieprzystosowania Rosjan do nowych warunków życia: „Общественной жизнью интересовались мало. Собирались больше под лозунгом русского борша, но небольшими группами, потому что все так ненавидели друг друга, что нельзя было соединить двадцать человек, из которых десять не были бы врагами десяти остальных. А если не были, то немедленно делались. Местоположение городка было очень странное. Окружали его не поля, не леса, не долины, - окружали его улицы самой блестящей столицы мира, с чудесными музеями, галереями, театрами. Но жители городка не сливались и не смешивались с жителями столицы и плодами чужой культуры не пользовались. Даже магазинчики заводили свои. И в музеи и галереи редко кто заглядывал. Некогда, да и к чему - «при нашей бедности такие нежности». [...] Они никогда не смеялись и были очень злы" [Тэффи 1999, 147-148].

Autorka zwracała uwage na brak zadomowienia starszego pokolenia emigrantów w obcej kulturze oraz trudny proces asymilacji, zob. m.in. esej O jezyku rosyjskim (О русском языке, 1926). „Я очень педантик на счет русского языка. Ведь это единственное, что у нас осталось. Сокровище наше" - konstatuje jeden z bohaterów N. Teffi (Rozmowa). Jednak język 
ojczysty w warunkach emigracji ulegał nieuchronnym transformacjom i tę bolesną prawdę obnażała Teffi w swoich opowiadaniach satyrycznych. Emigrantka twierdziła, że utrata ojczyzny prowadziła do utraty języka, a ta z kolei do utraty kodu kulturowego ${ }^{7}$. Bohaterowie jej opowiadań toczą zażarte spory językoznawcze, jak na przykład w opowiadaniu Rozmowa (Разговор), z których jeden sfrancuził sie, a drugi - mylił słowa rosyjskie z niemieckimi: „Постойте, не сбивайте. Потому что есть свекровь и есть сноха, это значит, жена снохача, и есть золовка, и есть невестка, золовкина сестра, что ли, а брат снохача - золовкин деверь... - А мерин, это кто кому как? - Ничего не помню. Придется в Ларуссе посмотреть. Беда!" [Тэффи 1999, 175-176].

Wymownie problem utraty tożsamości przez rosyjskich emigrantów Teffi wyraziła w opowiadaniu Ke fer? (od fr. Que faire w znaczeniu Co robić?), opublikowanym 27 kwietnia 1920 roku w pierwszym numerze gazety „Последние новости". Bohater, rosyjski generał, który zabłądził w Paryżu, wypowiada znamienne słowa: „Всё это, конечно, хорошо, господа! Очень даже всё хорошо. А вот... ке фер? Фер-то ке?” [Тэффи 1998, 126]. Fraza „co robić?" wyrażała fundamentalne dla emigracyjnej egzystencji pytanie, stawiane przez tych, których bieg wydarzeń zmusił do opuszczenia kraju i narzucił pełną bólu i wyrzeczeń dolę wygnańca.

W emigracyjnym dorobku Teffi możemy wyróżnić grupę tekstów, w których autorka wyrażała troskę o tożsamość językową przyszłych pokoleń. Bohaterami tomików Księga czerwiec (Книга июнь, 1931), O delikatności (О нежности, 1938), Ziemska tęcza (Земная радуга, 1952) są dzieci - ofiary emigracyjnego żywiołu i zderzenia dwóch kultur - niezrozumiane przez bliskich, nieznające języka ojczystego, nierozumiejące nowej rzeczywistości. „Все на свете вообще так сложно. В школе одно, дома другое. В школе - лучшая в мире страна Франция... Дома - надо любить Россию, из которой убежали" 8 - wyznaje jeden z małych bohaterów [Тэффи 2011]. Najbardziej wymownym przykładem pozostaje bohaterka opowiadania Pod znakiem waluty (Под знаком валютьь), dziewczynka o imieniu Chanum, pozbawiona na obczyźnie kontaktów z rodziną i językiem ojczystym: „- Странная ваша девочка, ваша Ханум, - сказал ей

7 Powyższe zjawiska, ze szczególnym uwzględnieniem wzajemnego oddziaływania czynników ekstralingwistycznych i systemowych w rozwoju języka oraz odmiany funkcjonalnej - mowy emigrantów, znalazły się w centrum uwagi wielu lingwistów i literaturoznawców, wśród których warto wyróżnić publikacje Lidii Granowskiej. Zob. [Грановская 1995; Грановская 1996, 126-136].

8 Pierwsza publikacja: Н.А. Тэффи, Гурон, „Возрождение” 1927, 27 lutego. 
кто-то. - Подумайте - ни семьи настоящей, ни родины, ни языка. [...] - Красная Шапочка пошла faire visite к своей бабушке, а бабушка жила в banlieue, там дешевле. Шапочка возмила с собой chocolat. Вот она бегала через лес. А в bois пристал к ней волк: «Xay $\partial y$ ю $\partial y ? »$. Шапочка заплакала en larmes, а волк побежал к дому, нажмил кнопку, хап, и съел бабушку (wyróżnienie - I.A.N.) [Тэффи 1998: 215].

Jednocześnie zagubienie $\mathrm{w}$ nowej kulturowej i językowej przestrzeni stawało się źródłem humoru sytuacyjnego i umożliwiało zabawy językowe. Przejawiało się to przede wszystkim w pomieszaniu dwóch języków, będących nie tyle parodia mowy emigrantów, ile metaforą ich bezradności wobec nieprzystosowania dwóch światów. Nasycenie wypowiedzi bohaterów wtrąceniami przede wszystkim wyrażeń z języka francuskiego, niekiedy też niemieckiego odnotowujemy we wszystkich zbiorkach emigracyjnych.

Zapis owych obcojęzycznych wtrąceń przybierał bardzo różnorodną formę:

a) wariant oryginalny

\begin{tabular}{|l|l|}
\hline \multicolumn{1}{|c|}{ Przykłady użycia } & \multicolumn{1}{|c|}{ Tytuł opowiadania } \\
\hline \multicolumn{1}{|c|}{ Pojedyncze słowa, zwroty i wyrażenia } \\
\hline Adieu & Наука и жизнь \\
\hline Asseyez-vous! & Ностальгия \\
\hline Carte d'identite & Дэзи и я \\
\hline C'est vous? & Две встречи \\
\hline Dames & Майский жук \\
\hline Danseur'a de madame & Наука и жизнь \\
\hline Des carottes & Гедда Габлер \\
\hline Eh bien? & Птичий день \\
\hline E'herbe & Ностальгия \\
\hline Elle comprend! & Башня \\
\hline Enfer & Эу \\
\hline Entrez & День \\
& Гедда Габлер \\
\hline Et a son amant & Воскресенье \\
\hline Fantaisies & Гедда Габлер \\
\hline La belle Irene & Две встречи \\
\hline Le tender Andre & \\
\hline
\end{tabular}




\begin{tabular}{|l|l|}
\hline \multicolumn{1}{|c|}{ Przykłady użycia } & \multicolumn{1}{|c|}{ Tуtuł ороwiadania } \\
\hline \multicolumn{1}{|c|}{ Pojedyncze słowa, zwroty i wyrażenia } \\
\hline Lions de mer & Шарль и Лизетта \\
\hline Madeleine & $\begin{array}{l}\text { Мещанский роман } \\
\text { Наука и жизьь }\end{array}$ \\
\hline Madelon & Мещанский роман \\
\hline Madame & $\begin{array}{l}\text { Две встречи } \\
\text { Гедда Габлер }\end{array}$ \\
\hline Maisons & Кэ фер? \\
\hline Messieurs & Майский жук \\
\hline Merci & Мещанский роман \\
\hline Monde & Птичий день \\
\hline Paradis & Эу \\
\hline Pardon & Мещанский роман \\
\hline Poste restante & Мещанский роман \\
\hline Saison morte & Мертвыи сезон \\
\hline Salle de bain & Файоклоки \\
\hline Tres moutarde & Кэ фер? \\
\hline \multicolumn{2}{|c|}{ Zdania } \\
\hline $\begin{array}{l}\text { Faut étre } \\
\text { Fidele a son mari } \\
\text { Regarde la grosse bebete! Vois-tu la grosse bebete }\end{array}$ & Воскресенье \\
\hline $\begin{array}{l}\text { A mon tender Andre } \\
\text { Ce ne peut pas durer longtemps } \\
\text { Je ne vous ai pas reconnu! } \\
\text { Mais au contraire } \\
\text { Pour un peu d'am-our! Pour un peu d'am-оu-r! }\end{array}$ & Две встречи \\
\hline J'ai mal au genou & День \\
\hline $\begin{array}{l}\text { Pour moi pas de lettre, madame? } \\
\text { Le temps est si beau! }\end{array}$ & Мещанский роман \\
\hline $\begin{array}{l}\text { Alons au Bois de Boulogne embrasser le bouleau } \\
\text { Le president de la republique }\end{array}$ & Ностальгия \\
\hline $\begin{array}{l}\text { Comme fourrure c'est tres pratique } \\
\text { Et c'est tres avantaguex } \\
\text { Non, merci, c'est trop lourd }\end{array}$ & Осколки \\
\hline $\begin{array}{l}\text { On y fait sa p'tite belote } \\
\text { Je cherche partout Titine }\end{array}$ & \\
\hline
\end{tabular}


b) słowa obce w transkrypcji rosyjskiej

\begin{tabular}{|c|c|}
\hline Przykłady użycia & Tytuł opowiadania \\
\hline \multicolumn{2}{|c|}{ Pojedyncze słowa, zwroty i wyrażenia } \\
\hline А резервуар! & Анна Степановна \\
\hline Гарсоны & L'ame slave \\
\hline $\begin{array}{l}\text { Кэс кэ ву завэ } \\
\text { Комман? } \\
\text { Па де жамбон? } \\
\text { Сил ву плэ }\end{array}$ & Как мьи прааздновали \\
\hline Кэскэсэ & Файфоклоки \\
\hline Ke фер? & Kə $е р е ?$ \\
\hline Мадам & Птичий день \\
\hline Мамзель & Восвресенье \\
\hline Мерси & $\begin{array}{l}\text { Две встречи } \\
\text { Воскресенье } \\
\text { Нелегкая } \\
\text { Виндетта } \\
\text { Маркита }\end{array}$ \\
\hline Мутон-шопы & Вспоминаем \\
\hline $\begin{array}{l}\text { Ное, рьен } \\
\text { Се комса }\end{array}$ & Наука и жизнь \\
\hline \multicolumn{2}{|c|}{ Zdania i wyrażenia złożone } \\
\hline $\begin{array}{l}\text { Et a son amant } \\
\text { Faut étre fidele a son mari } \\
\text { Regarde la grosse bebete! Vois-tu la grosse bebete }\end{array}$ & Воскресенье \\
\hline $\begin{array}{l}\text { A mon tender Andre } \\
\text { Ce ne peut pas durer longtemps } \\
\text { Je ne vous ai pas reconnu! } \\
\text { La belle Irene } \\
\text { Le tender Andre } \\
\text { Mais au contraire } \\
\text { Pour un peu d'am-our! Pour un peu d'am-ou-r! }\end{array}$ & Две встречи \\
\hline J'ai mal au genou & День \\
\hline $\begin{array}{l}\text { Pour moi pas de lettre, madame? } \\
\text { Le temps est si beau! }\end{array}$ & Мещанский роман \\
\hline $\begin{array}{l}\text { Alons au Bois de Boulogne embrasser le bouleau } \\
\text { Le president de la republique }\end{array}$ & Ностальгия \\
\hline $\begin{array}{l}\text { Comme fourrure c'est tres pratique } \\
\text { Et c'est tres avantaguex } \\
\text { Non, merci, c'est trop lourd }\end{array}$ & Осколки \\
\hline $\begin{array}{l}\text { On y fait sa p'tite belote } \\
\text { Et puis sa va } \\
\text { Je cherche partout Titine }\end{array}$ & Шарль и Лизетта \\
\hline
\end{tabular}


c) wypowiedzi przybierające postać „hybryd językowych”

\begin{tabular}{|c|c|}
\hline Przykłady użycia & Tytuł opowiadania \\
\hline Но ее совсем не видно этой saumon supreme. & Воскресенье \\
\hline $\begin{array}{l}\text { Пригла и сказала бы: Давайте пять тысяч pour mes } \\
\text { pauvres. Что бы ты тогда? А? }\end{array}$ & $\begin{array}{l}\text { Житие Петра } \\
\text { Иваньча }\end{array}$ \\
\hline $\begin{array}{l}\text { Комман? Па де жамбон? Ну уж это, знаете свинство! } \\
\text { Он говорит, что па дэ эамбон. Что? Кафэ о лэ? } \\
\text { Кф о пля? Сам лопай! Идем, господа, отсюда. }\end{array}$ & Как мы праздновали \\
\hline $\begin{array}{l}\text { Я ему говорю, если ты не будешь думать о семье, то } \\
\text { кто же будет? Нужно платить femme de menage, он } \\
\text { прекрасно это знает... }\end{array}$ & Крьллья \\
\hline Экутэ! Пардое мосье силь ву плэ - ле ресторан & Любовь \\
\hline $\begin{array}{l}\text { Пока что, пойдем на sold'bl покупать обжэ де люкcbl: } \\
\text { ломаную картонуи, рыжий берет - последний крик } \\
\text { умирающей моды... }\end{array}$ & Мертвый сезон \\
\hline Но ведь это ихняя $e$ 'herbe, а не наша травка-муравка. & Ностальгия \\
\hline
\end{tabular}

Językowe rozdwojenie emigranta było również obrazowane za pomocą przeinaczeń słownych czy też zapisu rosyjskiego tekstu w transkrypcji francuskiej lub zapisane alfabetem łacińskim, podobnie jak to lubił czynić Nabokov z ulubionymi wierszami rosyjskimi. Obrazuje to przykład z opowiadania Miłość (Любовь): „Qu'est ct que c'est lapicha? Qu'est ce que c'est babicha? Qu'est ce que c'est konopla?". Tym samym celom służył również sposób charakteryzowania postaci poprzez wyeksponowanie charakterystycznej leksyki, konstrukcji gramatycznych, wyrażeń metaforycznych, sposobu artykulacji czy maniery językowej i intonacji.

Obcojęzyczna leksyka obejmowała przede wszystkim różnego typu nazewnictwo, co miało podkreślać funkcjonowanie w nowej/obcej przestrzeni kulturowej:

\begin{tabular}{|c|c|}
\hline Nazewnictwo & Tytuł opowiadania \\
\hline \multicolumn{2}{|c|}{$\begin{array}{c}\text { Nazwy obiektów topograficznych } \\
\text { (miejscowości, dzielnic, ulic, parków, dworców, hoteli itd.) }\end{array}$} \\
\hline $\begin{array}{l}\text { Paris } \\
\text { Province }\end{array}$ & День \\
\hline Нотр-Дам & Майский жук \\
\hline $\begin{array}{l}\text { Шан, по Шан железе } \\
\text { бульвар Капустин } \\
\text { Роялс }\end{array}$ & Анна Степановна \\
\hline Трокадеро & Башня \\
\hline
\end{tabular}




\begin{tabular}{|c|c|}
\hline Nazewnictwo & Tytuł opowiadania \\
\hline \multicolumn{2}{|c|}{$\begin{array}{c}\text { Nazwy obiektów topograficznych } \\
\text { (miejscowości, dzielnic, ulic, parków, dworców, hoteli itd.) }\end{array}$} \\
\hline Ha Rue de la Paix & Две встречи \\
\hline $\begin{array}{l}\text { Аршанж, Агранж, Шаныиль, Банвиль } \\
\text { „Jaredin des Plantes” }\end{array}$ & Вспоминаем \\
\hline «Бристоль. Варшава» & Дачный сезон \\
\hline Булонский лес & Наука и жизнь \\
\hline Bois de Boulogne & Птичий день \\
\hline $\begin{array}{l}\text { Лионский вокзал } \\
\text { Rue Daru } \\
\text { Rue du Rhone }\end{array}$ & Мещанский роман \\
\hline $\begin{array}{l}\text { Kléber } \\
\text { Rue de Rome } \\
\text { Passy } \\
\text { Rive gauche } \\
\text { Этуали } \\
\end{array}$ & Квартирка \\
\hline Плас де ла Конкорд & Kэ фер? \\
\hline Contexeville & Мертвый сезон \\
\hline Foire de Paris & Шарль и Лизетта \\
\hline \multicolumn{2}{|c|}{ Nazwy tytułów utworów literackich, sztuk teatralnych } \\
\hline $\begin{array}{l}\text { Le danseur de Madame } \\
\text { L bonheur de ma femme } \\
\text { Le papa de maman } \\
\text { La maman de papa } \\
\text { La maman de maman } \\
\text { Le mari de mon mari } \\
\text { Le mari de ma femme }\end{array}$ & Воскресенье \\
\hline $\begin{array}{l}\text { Секвана, Сена } \\
\text { Ригвош } \\
\text { Пасях }\end{array}$ & Городок \\
\hline Гранд Отель & $Э y$ \\
\hline \multicolumn{2}{|c|}{ Nazwy dań kuchni francuskiej } \\
\hline $\begin{array}{l}\text { Cotelette d'agneau } \\
\text { Boeuf frit } \\
\text { Chateaubriant } \\
\text { Lapin } \\
\text { Gigot } \\
\text { Poulet } \\
\text { Saumon supréme }\end{array}$ & Воскресенье \\
\hline $\begin{array}{l}\text { Crème a la reine Sadanapale de la Montegut } \\
\text { Bombe duchesse du Rond-Point a la Recamier } \\
\text { Pergolese de Montmorency }\end{array}$ & $Э y$ \\
\hline
\end{tabular}


Ważną rolę w twórczości Teffi pełnił obraz Paryża - jeden z największych centrów kulturalnych emigracji rosyjskiej. Przestrzenna organizacja opowiadań emigracyjnych korelowała z realną topografią miasta (ulice, place, dworce, parki itd.). Paryż był traktowany przez Teffi jako swego rodzaju „znak kulturowy” przeciwstawiony innym „znakom”, przede wszystkim - Rosji. Opowiadania emigracyjne Teffi stanowią niezwykłym przewodniki po „rosyjskim Paryżu”. W swoich utworach autorka skrupulatnie odtwarzała ulubione miejsca spotkań i spacerów. Teffi była jedną z nielicznych pisarek rosyjskiej emigracji, które w swojej twórczości wydzieliły tak obszerną przestrzeń w celu przedstawienia życia na obczyźnie. Wszak pisarze rosyjscy starszego pokolenia konsekwentnie unikali ujęcia tej sfery ich doświadczenia ${ }^{9}$.

Podsumowując nasze rozważania, należy podkreślić, że wzajemne uwarunkowania i związek pomiędzy językiem i tożsamością w bezpośredni sposób określają status pisarzy emigracyjnych. Przedstawiciele pierwszej fali emigracji rosyjskiej przejawiali postawę heroiczną reprezentowania Rosji za granica (,swoje” i „obce” w tym paradygmacie to przeciwieństwa). Pisarze ci rezygnowali z pełnej asymilacji z kulturą większości (brak zgody na wchłonięcie tego, co „swoje”, przez „obce”). To wszystko dowodzi złożoności problemu tożsamości językowej rosyjskich pisarzy emigracyjnych, którzy niejednokrotnie stawali w obliczu trudnych wyborów egzystencjalnych i twórczych.

\section{Literatura}

Anusiewicz J., 1991, Kulturowa teoria języka. Zarys problematyki, [w:] Język a kultura, red. J. Anusiewicz, J. Bartmiński, t. 1, Wrocław.

Czapik B., 1992, Budowanie tożsamości, doświadczenie kryzysu, [w:] Kryzys tożsamości: slavica, red. B. Czapik, E. Tokarz, Katowice, s. 7-14.

Fishman J., 1996, What Do You Lose When You Lose Language?, [w:] Stabilizing Indigenous Languages, ed. G. Cantoni, Flagstaff, s. 2-3, [online], http://www. ncbe.gwu.edu/miscpubs/stabilize/iii-families/lose.htm [11.11.2017].

Helbig-Mischewski B., 2009, Penis w opałach. Doświadczenia kastracji i strategie odzyskiwania mocy w literaturze kilku migrantów polskich w Niemczech, "Teksty Drugie" nr 6, s. 160-161.

Joseph J.E., 2004, Language and Identity, National, Ethnic, Religious, Basingstoke.

9 Dla przykładu przypomnijmy, iż spośród trzydziestu opowiadań napisanych z dala od ojczyzny przez noblistę Iwana Bunina, tylko dwa były poświęcone środowisku emigracji. 
NDiaye I.A., 2008, Hipertrofia tęsknoty za utraconym domem w poezji emigrantów rosyjskich „pierwszej fali”, Olsztyn.

Sałajczykowa J., 2003, Prozaicy pierwszej fali emigracji rosyjskiej 1920-1940, Gdańsk.

Tarnowska B., 2004, Między światami. Problematyka bilingwizmu w literaturze. Dwujezzyczna twórczość poetów grupy „Kontynenty”, Olsztyn.

Abdank-Kossovskij V., 1956, Russkầ èmigraciâ. Itogi za tridcat' pât' let, „Vozroždenie", nr 51, s. 127. [Абданк-Коссовский В., 1956, Русская эмиграчия. Итоги за тридиать пять лет, „Возрождение”, nr 51, s. 127.]

Granovskaâ L.M., 1996, Russkij Monparnas: Zametkio âzyke èmigrantskoj poèzii pervoj volny, [w:] Âzyk itvorčestvo. Sbornik statej k 70-letîu V.P. Grogor'eva, Moskva, s. 126-136. [Грановская Л.М., 1996, Русский Монпарнас: Заметки о языке эмигрантской поэзии первой волньь, [w:] Язык и творчество. Сборник статей к 70-летию В.П. Грогорьева, Москва, s. 126-136.]

Granovskaâ L.M., 1995, Russkij âzyk v «rasseânii»: Očerki po âzyku russkoj èmigracii pervojvolny, Moskva. [Грановская Л.М., 1995, Русский язык в «рассеянии»: Очерки по языку русской эмиграции первой волнь, Москва.]

Kodzis B., 2002, Puti razvitiâ russkoj èmigrantskoj literatury mežvoennogo perioda, [w:] Duchowość i sacrum w literaturze emigracyjnej Stowian Wschodnich, red. A. Woźniak, M. Kawecka, Lublin. [Кодзис Б., 2002, Пути развития русской эмигрантской литературы межвоенного периода, [w:] Duchowość i sacrum w literaturze emigracyjnej Stowian Wschodnich, red. A. Woźniak, M. Kawecka, Lublin.

Kodzis B., 2001, Puti razvitiâ russkoj èmigrantskoj literatury mežvoennogo perioda, [w:] Literatura rosyjska w kontekstach międzykulturowych, red. J. Lukszyn, Warszawa, s. 130-149. [Кодзис Б., 2001, Пути развития русской эмигрантской литературь межвоенного периода, [w:] Literatura rosyjska w kontekstach międzykulturowych, red. J. Lukszyn, Warszawa, s. 130-149.]

Nakašidze I.S., 2014, Kačestvožizni naseleniâa v usloviâh modernizacii rossijskogo obŝestva: Pravovye, sociokul'turnye isocial'no-èkonomičeskie aspekty, [w:] Sb. statej VII Vserossijskoj naučno-praktičeskoj konferencii, Penzenskij gosudarstvennyj tehnologičeskij universitet, Penza, s. 114-118. [Накашидзе И.С., 2014, Качество жизни населения в условиях модернизачии российского общества: Правовье, сочиокультурнье и сочиально-экономические аспекты, [w:] Сб. статей VII Всероссийской научно-практической конференции, Пензенский государственный технологический университет, Пенза, s. 114-118.

Nakašidzei S., Nacional'nâ̂a identičnost' i literatura v usloviâh èmigracii [Накашидзе И.С., Начиональная идентичность и литература в условиях эмиграции [Препринт], [online] http://eadnurt.diit.edu.ua/bitstream/1234567 89/3396/1/Nakashydze_1.pdf [12.10.2017]. 
Raev M., 1994, Rossiâ za rubežom. Istoriâ kul'tury russkoj èmigracii 1919-1939, Moskva. [Раев М., 1994, Россия за рубежом. История культуры русской эмиграции 1919-1939, Москва.]

Tèffi N.A., 1927, Gorodok. Novye rasskazy, Pariž, s. 5-7. [Тэффи Н.А., 1927, Городок. Новье рассказы, Париж, s. 5-7.]

Tèffi N.A., 1998, Sobranie sočinenij, t. 3: Gorodok, sost. i podgotovka tekstov D.D. Nikolaeva i E.M. Trubilovoj, Moskva. [Тэффи Н.A., 1998, Собрание сочинений, т. 3: Городок, сост. и подготовка текстов Д.Д. Николаева и Е.М. Трубиловой, Москва.]

Tèffi N.A., 2011, Sobranie sočinenij, t. 4: Kniga iûn'. O nežnosti [Тэффи H.A., 2011, Собрание сочинений, т. 4: Книга июнь. О нежности], [online] http: //ogrik2.ru/b/nadezhda-aleksandrovna-teffi/tom-4-kniga-iyun-o-nezhnosti/ 23538 [11.11.2017].

Čelyšev E.P., 1993, Prolog, [w:] Literatura russkogo zarubež'â. 1920-1940, sost. i otv. red. O.N. Mihajlov, Moskva, s. 32. [Челышев Е.П., 1993, Пролог, [w:] Литература русского зарубежья. 1920-1940, сост. и отв. ред. О.Н. Михайлов, Москва, s. 32.]

\section{ON THE IDENTITY OF THE RUSSIAN EMIGRATION LITERATURE (NADEZHDA TEFFI'S PROSE)}

\section{S U M M A R Y}

The subject of the analysis is the Nadezhda Teffi (Buczynska, borne Lokhvicka, 1872-1952) journalistic publicatios and the emigration prose. She spent more than thirty years in exile in Paris. The author focuses on the issues of linguistic identity of Russian emigration literature, with particular emphasis on the cultural context.

The conducted analysis proves for that the representatives of the first wave of Russian emigration the mother tongue had a great importance. In addition to the communication function, he served two basic functions: information - as a way of creating and disseminating knowledge, values, traditions, etc., and integrating that reflected the emotional attitude to language. That is why Russian emigrants, although they knew foreign languages, mainly French and German, remained faithful to their homeland. At the same time, however, the works of emigrants were saturated with references to foreign languages. 